\title{
Forget the Future: Our Time is Now
}

\author{
R. David Lankes \\ University of South Carolina
}

Abstract: The text of a 2017 address at the RUSA President's program talks about the need for librarians to be centered on active learning. Aspects of continuous learning for librarians should be participatory, happening everywhere, and occurs in a social context. The author argues that librarians must be advocates and must advocate for everyone in the community regardless of race, religion, education level, or country of origin. This is a job that cannot be delayed until tomorrow. It is a duty outlined in the values of our profession and enabled by technology. The article ends with a call for personal action in supporting communities of all types.

Keywords: reference, learning, activism, advocacy

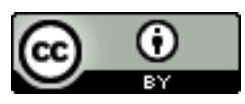

This is an Open Access article distributed under the terms of the Creative Commons Attribution 4.0 International License (http://creativecommons.org/licenses/by/4.0), which permits unrestricted use, distribution, and reproduction in any medium, provided the original work is properly cited. 
Every year the University of South Carolina's School of Library and Information Science have a hooding ceremony for graduating librarians in Rutledge Chapel on the historic Horseshoe of campus.

The chapel is in Rutledge College, the first building built for the South Carolina College - now the University of South Carolina - in 1805. It was built, in part, with slave labor.

Before the Civil War students and faculty brought their slaves to college. During the war the building served as a hospital for wounded Confederate soldiers.

It is remarkable then that after the war, during the period of reconstruction, Rutledge was opened as The State Normal School that prepared African American woman to be teachers. Faculty of all genders and colors lectured in its halls.

If I was to end the story there, it would be one of redemption, and pride. However, it doesn't end there. After Northern troops withdrew from Columbia, the newly elected white male Governor closed the school, dismissed the integrated board of trustees, and reopened the university in 1880 as an all-white, all-male institution.

It would be 83 years before the university accepted another African American student in 1963 The same year as Martin Luther King's March on Birmingham and Washington.

I tell this history to the graduating librarians for the same reason I tell you: in a profession that professes diversity and empowerment to all through knowledge, we can never take social progress for granted. Progress in what we know and who we include in that knowledge - even the definition of what constitutes knowledge - requires the continuous dedicated work of an engaged citizenry. In our neighborhoods, in our academies, our halls of government, our industry, and our communities of faith there is needed advocates for an improved society. 
Today, I will make the case that you, as librarians first, but particularly as reference librarians, must be among those advocates and must advocate for everyone in the community regardless of race, religion, education level, or country of origin. This is a job that cannot be delayed until tomorrow. We need to be community advocates not because that is some future strategy, or a direct response to falling reference questions. It is a duty outlined in the values of our profession and enabled by technology.

Before I get into the how's and why's, let me be clear. This is not about resistance, or an ideological reaction to the last national election. I am not asking you to mobilize as liberals or conservatives, democrats or republicans. However, what I am asking you is to be political, because it is about power and participation in a democratic society and often power and participation in the service of those that have none.

You cannot empower a person or community if you have no power to give. Literacy, for example, is a necessary skill to be a full member of today's society - reading and writing are the power to embrace and add to the cultural discourse. Reading is power, and if we seek to empower others, it is a power we must first possess: you must be able to read to teach others to do so. Likewise, to empower others in information literacy or research or career seeking, we must first have that power ourselves. The dispensation of power - granted by taxpayers, trustees, partners, or superintendents - is a political process.

If you think that inspiring the love of reading, providing access to the latest research in a discipline, maintaining an open community space, or providing instruction are somehow neutral or objective aims, then you don't understand why a white male governor closed my university to former- 
slaves in the 1800's. There is great truth to the saying the "knowledge is power," and the goal of librarians is to facilitate a more knowledgeable community - a more powerful community.

This mission - building a more knowledgeable community - can be traced back to the origins of libraries millennia ago. However, these roots are even more obvious when we look at the emergence of libraries in the U.S.. Public libraries as we know them today grew out of a social movement. The same social movement that took children out of factories and created public schools. It was Melvil Dewey that said that a public library is a co-equal educational institution to the public school. Carnegie funded libraries to support a population that sought to govern itself.

Of course, how librarians achieve this more knowledgeable community is up for debate. Over the past century, we have seen the way in which librarians sought to support our society shift dramatically. In academic libraries, we have seen librarians as professors of the humanities give way to a corps of library professionals with ever escalating academic preparation. In the public libraries, we saw a focus on limited collections to the embrace of fiction, media, and today the advent of learning spaces with a focus on makers.

One of my favorite books is Wayne Wiegand's Part of our lives: A people's history of the American public library. In it he quotes a California newspaper editorial railing against a new item type being collected by the public library, saying that it would only interest:

“...schoolchildren; factory and shop girls; men who tended bar, drove carriages, and worked on farms and boats; and finally, fallen women, and, in general, the denizens of the midnight world, night-owls, prowlers, and those who live upon sin and its wages" (Wiegand, 2015, p. 60)

That item type? The literary novel. Today it is common knowledge that novels and fiction are the core of inspiring reading in our libraries. However, that is only because of the conscious, 
coordinated, and sustained efforts of librarians seeking to improve their communities. Further, this sustained effort is guided by a set of explicit principles.

Today, I argue that continuing this mission - the improvement of society through facilitating knowledge creation - or more simply, learning- within our communities requires a different tact. Reference librarians must now fully embrace a mission of learning. We must understand that a reference interview is not simply a question and answer transaction, but a highly customized and compressed instructional session. The programs we offer, the collections we build, the LibGuides we write, and the consultation we do are all learning activities.

The focus on learning is hardly new. In 1939 - at the end of the Great Depression and in the face of Jim Crow and Segregation - ALA put forth a Code of Ethics in which the authors stated "Librarians should recognize librarianship as an educational profession and realize that the growing effectiveness of their service is dependent upon their own development." (American Library Association, 2008). For too long librarians have seen their work as merely access to information. Access to information without explicit mechanisms of instruction and learning is at best a slogan, and at worst a dereliction of duty. Let me be clear: this applies to all of librarianship, not just instructional librarians, or communityoutreach librarians, but ALL librarians. If you catalog a book - that is an instructional activity. If you answer a reference question, that is an instructional activity. Check out an item, sit in a chamber of commerce meeting, story time, research support, building maintenance, mange volunteers, metadata schema development, operate an institutional repository, edit an open access journal, publish a paper, conduct a survey - these are all instructional activities that can only be assessed against a single criterion: did the community - the WHOLE community - get smarter. 
There are some serious consequences of putting learning at the center of what we do. These consequences are probably most evident, however, in how we conduct and conceptualize reference work. I will tackle 3 of these: learning is participatory, learning happens everywhere, learning occurs in a social context.

\section{Learning is Participatory}

If there is one thing that separates the history of librarianship from formal education, it is the understanding that people learn, they are not taught. Formal education at the primary, secondary, and post-secondary levels were, and in some cases, still are, set up around the idea that we teach people. The industrial model of education that places 30 students in a classroom, or hundreds in a lecture hall, pre-supposes that if we can craft the delivery of material just right we can educate. If the professor can just give a compelling enough lecture, or the teacher can sequence the material just so, students will learn.

In libraries, however, we have been mostly set up to serve the engaged learner. We assume that some motivation is driving a person to learn, and so we wait at desks or in buildings, or at the end of chat windows for people to ask us questions or seek materials.

What we now know in education and the learning sciences, is that both of these approaches are incomplete. People are neither empty buckets waiting for an instructor to toss in bricks of knowledge into them, nor are they disembodied questions in search of "the answer." What we now know is that people are not taught, they learn. What's more they learn through engaged dialog. Call it critical thinking, or metacognition, or simply conversation, people learn by interactions over time with experts, resources, and always, with themselves. They take in information, relate it to what they already know, and, if it fits in their worldview, they expand or correct what they know. 
This means that lecturing at someone for an hour is as useless as throwing 30 documents at them in terms of learning if neither the lecturer or the librarian first take account and accommodate an ongoing internal dialog.

Take, for example, studies that show that when a person holds an incorrect understanding of a topic, showing them correct information not only doesn't change their minds, it actually causes that person to more deeply believe the incorrect situation. Or, put another way, saying that $99 \%$ of scientists support the idea of man-made climate change not only isn't persuasive to climate change deniers - it could actually lead them to strengthen their doubt.

What does make a difference is scaffolding new ideas, and even contradictory ideas, upon what a person already holds to be true. In education, this is often referred to as constructivism. People construct their knowledge.

This means that simply "informing" someone is not going to achieve our mission of a smarter community. We must engage them in a dialog. We must test what they currently believe, and then build to a new view of the world... which we will come back to in a moment. Issues of trust, language, and bias always play a role in how well we serve anyone. As reference librarians, we must become expert in relationships, not transactions. We must seek out trust and sustained conversations, not be objective answer generators.

One of the best examples of this today comes from my favorite reference superhero, Nicolette Sosulski. Her recent work on supporting grieving patrons shows not only excellence in searching, but empathy for people in crisis. Put simply, it matters if people are grieving, or hungry, or scared. If we want people to learn, we must first see them as people living a complex life and that only happens over 
time. We must also acknowledge that different members of our community are neither afforded the same opportunities for advancement nor is the best course of action forcing our ideals upon them.

\section{Learning Happens Everywhere}

Just as the people who seek out help are ultimately in control of their learning, so too do they seek to be in control of the environment where they learn. On the surface this seems both intuitive and a simple call for leaving our buildings. Yes, we must increasingly leave our buildings and do our work in the classrooms, board rooms, laboratories, and town halls. However, that's not my focus here. My focus here is the reason why we need to be there.

The answer is because increasingly the learning spaces of todays are virtual, provided by commercial interests, and prone to be bubbles of group think. Yes, this is the Facebook problem. However, it is also the problem we see with the systematic dismantling of the public square due to pressures for development and concerns about security. This is our K-12 schools where students play football in stadiums sponsored by soda vendors and listen to commercials on their bus rides home. This is a push in higher education to mine and sell the data of students to lower tuition costs. This is the data acquired by software vendors from library provided ebooks and databases.

To be clear, I am not, as some of my colleagues do, calling for a complete abandonment of private public/partnerships. Rather it is a call for librarians, and in particular reference librarians to be in these spaces and to both be aware and make those we serve aware of the influence these partnerships bring. We are not objective or unbiased, but we damn well better be observant and vocal. 


\section{Learning Occurs in a Social Context}

As we learn, we adjust our worldview... how we see and relate to the world. In many ways that view is very particular to ourselves. It is a strong part of our personality. However, that worldview is constantly being tested as it rubs up against reality and, more importantly, each other. In this way, how we see the world is strongly influenced by those around us. Our world view is social.

It is these two factors - that worldviews are individual, but constantly shaped by the many that speak to our respect for diversity. The more diverse the environment in which we learn, the richer our world view. It is the exact same reason we promote intellectual freedom - the more diverse the sources of learning, the richer the learning.

This is important, because it means to facilitate knowledge is not just about how one person learns, but how that learning fits into a larger social context and a larger social justice I would add. So, just as librarians help weave together understandings of the one, we must also weave together the understandings of the whole - the community. To do this, we must actively reach out to those in our buildings and well beyond.

To embrace and promote diversity in learning, we must constantly encounter diverse views and individuals within our communities. That includes those we agree with, and those that we don't. Those with power and those without. Those with privilege, but even more importantly, those without. The purpose of this outreach is a smarter community, and smarter is ultimately a benchmark determined in close and intentional consultation with the community itself.

This is why the answer to fake news and filter bubbles is not simply more information literacy instruction. What is broken in our communities is not a sophistication of information consumption, but a lack of common meanings and values. This is not as simple as belief versus science, or liberalism 
versus nativism. This is about communities holding common understandings or values, and the means to handle disagreements in these values. We will not have a more civil discourse until we act more as one civilization and not camps. You can't teach a class on common values, you can't build a webinar to tell people common principles, you can only bring together parties, provide a fair and equitable table, and argue to the truth - no matter how uncomfortable that truth is. Reference librarians are not bringers of truth, or teachers of information literacy, they are referees in the most consequential conversation of our time... what does it mean to be a community.

To be clear librarians are not neutral or passive players in these conversations. We want this to be an informed dialog where the parties can refer to common evidence and documents. We are not passively waiting at desks for the parties to come together - we reach out and we go to the places these conversations are already occurring.

\section{This is Our Job}

Why us? Who appointed librarians to facilitate this conversation? The short answer is the communities we serve. For some libraries, this is a charter issued by the state. For others, it is a place on the org chart. For academic libraries, it might be the requirements of an accrediting agency. For school libraries, it may be (should be) encoded into education law. In all cases librarians have been given power by the community to help inform and educate.

A library is not, nor has it ever been, simply a collection or a building. It has been a mandate of the people - stewarded by librarians and dedicated to learning. In the public sphere we are seeing a retreat of public service. Town hall is increasingly seen as a battleground of ideology, and the safety net is fraying. Teachers are locked into testing schemes; social workers overburdened. It is up to librarians to use our tools and skills to reach out and seek common ground. We are connected to our 
communities and we know our neighbors. We must be a missionary force going into the town and seeking out diversity and knitting it into a new community fabric for all.

In our universities, we see the competing pulls of teaching, research and service. We see our disciplines grow more specialized as our problems grow more interdisciplinary. We are the intellectual professionals who must undergird our academies not just with resources, but connection, reflection, and instruction.

In our schools, many libraries are the last refuge of the curious mind. School librarians provide the ever-important area of reflection, personal inquiry, and intellectual diversity. We must be the glue that binds the curriculum.

In our governments and our businesses, and our vendors, reference librarians must stop trying to emulate some sort of search engine and seek knowledge over data and hits. People are not algorithms. The current data-centric view of industry and decision makers will not free people, it will transform them into data points shoveling data into our modern-day steam engines.

This is not the talk of a luddite, or a technophobe. Librarians embrace the new and the modern. Technology liberates us all from the burden of repetition, but that liberty should not come at the cost of privacy, diversity, and whimsy.

\section{Conclusion}

In 1963 "Henrie D. Monteith, Robert Anderson and James Solomon became the first AfricanAmerican students to enroll at the university [of South Carolina] in the 20th century; in 1965, Monteith became the first African-American graduate, earning a B.S. in biochemistry." (University of South Carolina, 2019, para 14). They did this because society looked at segregation and Jim Crow laws and decided that diversity and integration were essential parts of society and education. This was not a 
universal conclusion, and many sacrificed their lives and liberty to bring about this change. Nor did racism and segregation end in 1963. It is a wrenching conversation, and wound, and reality that impacts African Americans, immigrants, and refugees to this very day. It is a conversation that will not simply go away if not confronted as we saw in the brutal killings at Charleston AME Church.

It is a conversation, with other conversations of LGBTQ rights, religious freedom, access to educational opportunities, a shifting workforce, growing wealth disparities, the role of government in our lives that are too important to be left unattended. These are conversations that will not be settled in Washington, they will be settled on the street corners, board rooms, and classrooms of our communities across the nation. They are conversations that are dangerous and high stakes. However, a library should be a safe place to explore dangerous ideas. Yet they will only be safe places if we, librarians, work to make them such. Nothing in the name library, or laws, or charters, or organizational charts makes a library safe. That is your job.

\section{References}

American Library Association (2008). Code of ethics of the American Library Association. Retrieved September 14, 2019 from: http://www.ala.org/advocacy/sites/ala.org.advocacy/files/content/proethics/codeofethics/Co de\%20of\%20Ethics\%20of\%20the\%20American\%20Library\%20Association.pdf

University of South Carolina (2019). Our history. Retrieved September 23, 2019 from: https://www.sc.edu/about/our history/

Wiegand, W. A. (2015). Part of our lives: A people's history of the American public library. New York: Oxford University Press. 